\title{
Polymorphic microsatellites in the human bloodfluke, Schistosoma japonicum, identified using a genomic resource
}

\author{
Ning Xiao ${ }^{1 *}$, Justin Remais ${ }^{2}$, Paul J Brindley ${ }^{3}$, Dongchuan Qiu', Robert Spear ${ }^{4}$, Yang Lei ${ }^{1}$, David Blair ${ }^{5}$
}

\begin{abstract}
Re-emergence of schistosomiasis in regions of China where control programs have ceased requires development of molecular-genetic tools to track gene flow and assess genetic diversity of Schistosoma populations.

We identified many microsatellite loci in the draft genome of Schistosoma japonicum using defined search criteria and selected a subset for further analysis. From an initial panel of 50 loci, 20 new microsatellites were selected for eventual optimization and application to a panel of worms from endemic areas. All but one of the selected microsatellites contain simple tri-nucleotide repeats. Moderate to high levels of polymorphism were detected. Numbers of alleles ranged from 6 to 14 and observed heterozygosity was always $>0.6$. The loci reported here will facilitate high resolution population-genetic studies on schistosomes in re-emergent foci.
\end{abstract}

\section{Findings}

The Asian bloodfluke, Schistosoma japonicum, causes serious human disease in several parts of eastern Asia, and in particular in China where more than 30 million people living in the tropical and subtropical zones are at risk [1]. On the heels of widespread progress in controlling S. japonicum over the past two decades [2], China is facing the challenges posed by re-emergence of schistosomiasis in localities where control activities have nearly ceased and where apparent elimination had been achieved $[2,3]$. In comparison to traditional assessment methods, molecular tools will be increasingly important as China targets regions with low prevalence and low infection intensity for elimination [4-6] on the path to reducing schistosome infection to less than $1 \%$ by 2015 [2]. Such tools will be important for high-resolution monitoring of infections in snails and in mammalian hosts, elucidating transmission networks, and improving the targeting of interventions to achieve final elimination of the disease.

This important pathogen has already received attention from population geneticists using microsatellites $[7,8]$. Most of the loci used had been found by

\footnotetext{
* Correspondence: ningxiao116@yahoo.com.cn

${ }^{1}$ Institute of Parasitic Diseases, Sichuan Center for Disease Control and

Prevention, Chengdu, Sichuan 610041, PR China

Full list of author information is available at the end of the article
}

examination of the GenBank accessions for S. japonicum data existing at that time or through testing of primers that amplified microsatellite loci in another bloodfluke, $S$. mansoni. A near-complete draft genome of $S$. japonicum has been released by the Chinese Human Genome Center in Shanghai [9] and the raw data are available at http://lifecenter.sgst.cn/schistosoma/cn/schistosomaCnIndexPage.do. An earlier study [10] reported 17 loci from this resource. In this study we report on additional loci suitable for research into gene flow in S. japonicum in Sichuan Province. Results of this search are presented here. We searched this resource for microsatellite loci using the following criteria:

- Repeats should be 2, 3 or 4-mer,

- The number of tandem repeats should be in the range $10-25$,

- Loci should not include compound repeats,

- Loci should be flanked by single-copy DNA sequences to which PCR primers could be targeted,

- Loci should be far apart so as to avoid linkage disequilibrium. In practice, since chromosomal assignment of super-contigs is unknown as yet, loci were selected from different super-contigs,

- Loci should not be in, or close to, known or predicted coding regions.
Ciomed Central

(c) 2011 Xiao et al; licensee BioMed Central Ltd. This is an Open Access article distributed under the terms of the Creative Commons Attribution License (http://creativecommons.org/licenses/by/2.0), which permits unrestricted use, distribution, and reproduction in any medium, provided the original work is properly cited. 
Table 1 Primer sequences and other characteristics for each of 22 microsatellite loci amplified from 20 specimens of Schistosoma japonicum

\begin{tabular}{|c|c|c|c|c|c|c|c|c|}
\hline $\begin{array}{l}\text { Locus } \\
\text { name }\end{array}$ & $\begin{array}{l}\text { Primer sequences } \\
\text { (tails removed) }\end{array}$ & $\begin{array}{l}\text { Repeat } \\
\text { unit }\end{array}$ & $\begin{array}{l}\text { Length of locus in } \mathbf{S j} \\
\text { Genome draft (excl tails) }\end{array}$ & $\begin{array}{l}\text { Length range (PCR } \\
\text { product - bp excl tail) }\end{array}$ & $\begin{array}{l}\text { No. of } \\
\text { alleles }\end{array}$ & $\begin{array}{l}\text { In } \\
\text { HWE? }\end{array}$ & Ho & $\mathrm{He}$ \\
\hline SjP4 & $\begin{array}{l}\mathrm{F}: \text { ACAAGCTCCAATCGTCTCTGA R: } \\
\text { GAATACTGCCGCCСTTGTAA }\end{array}$ & TAA & 217 & $182-244$ & 14 & & 0.789 & 0.831 \\
\hline SjP9 & $\begin{array}{l}\text { F : GATGAAACAGATACCCAGCAC R: } \\
\text { TGCATGTAAAAATGGCTTGC }\end{array}$ & TAA & 283 & $239-301$ & 14 & $* *$ & 0.600 & 0.915 \\
\hline SjP18 & $\begin{array}{l}\text { F : TCCTTTATCTGGGCTGTGGA R : } \\
\text { TTTCAGCAGGATAACATGACG }\end{array}$ & TGA & 286 & $261-298$ & 7 & & 0.684 & 0.703 \\
\hline SjP19 & $\begin{array}{l}\text { F : GGTATCTTCGCTTTTTAGCATGG } \\
\text { R : TCCTAGGGTGTGGTATCAGAG }\end{array}$ & ATT & 196 & $161-257$ & 12 & $* *$ & 0.737 & 0.896 \\
\hline SjP22 & $\begin{array}{l}\mathrm{F}: \text { CAAAGCCTAAACGTCATAGACAG } \\
\mathrm{R}: \text { CAACCACCGATAAGTAGAGTGGA }\end{array}$ & TTA & 150 & $105-167$ & 11 & * & 0.850 & 0.892 \\
\hline SjP23 & $\begin{array}{l}\text { F : GTACGATATGAGGGAAAGTTCA R: } \\
\text { CTCTCCTTCAGACGAATTGAG }\end{array}$ & TAA & 219 & $192-253$ & 14 & & 1.00 & 0.933 \\
\hline sjP26 & $\begin{array}{l}\text { F : CAAGGGAACATTGTACATGAAG R: } \\
\text { TGGTAAAGGAGAAAGTGAACG }\end{array}$ & TAA & 307 & $229-312$ & 7 & & 0.700 & 0.659 \\
\hline SjP2 8 & $\begin{array}{l}\text { F : TAACGCCTTTTCCCACATTC R: } \\
\text { ATAACCACGATGGGAACCAA }\end{array}$ & TTA & 242 & $232-269$ & 13 & $* *$ & 0.900 & 0.926 \\
\hline sjP32 & $\begin{array}{l}\text { F : TGTCACCGAGTCTTCATTAGC R: } \\
\text { ACAGTCAGTAGACCTGGATAAAC }\end{array}$ & TTA & 175 & $142-192$ & 14 & & 0.950 & 0.929 \\
\hline SjP34 & $\begin{array}{l}\text { F : GGCGACCATACATAAGGAGAAT R : } \\
\text { GACCGATTTCTAATGGAGCA }\end{array}$ & TAA & 409 & $381-430$ & 13 & * & 0.778 & 0.908 \\
\hline SjP3 7 & $\begin{array}{l}\text { F : TCCTTGACACGAGGTACATGT R: } \\
\text { ATTACGTAACAGAAGGCTGGA }\end{array}$ & $\mathrm{TAT}$ & 290 & $240-314$ & 8 & & 0.833 & 0.714 \\
\hline SjP39 & $\begin{array}{l}\text { F : GACGACTGTTAAGTCCATCTGA R: } \\
\text { ATAACCAATCTCCACGAAAGC }\end{array}$ & ATT & 239 & $223-251$ & 8 & & 0.900 & 0.871 \\
\hline SjP42 & $\begin{array}{l}\text { F : GCTGCAGCTTCTGTGTAGTAA R : } \\
\text { GTCTTGCTCAGATCAGTTCGT }\end{array}$ & TAA & 216 & $199-234$ & 9 & & 0.950 & 0.855 \\
\hline SjP43 & $\begin{array}{l}\text { F : ACAATGGCTATTGGTTGAGTAG R : } \\
\text { GGAGCATGCGTATATGGAAAA }\end{array}$ & TAA & 188 & $184-235$ & 9 & & 0.750 & 0.854 \\
\hline SjP4 5 & $\begin{array}{l}\text { F : ATAACACCGAATCTGTTCAGC R : } \\
\text { TAATCCGGTCAGGATGTATGT }\end{array}$ & TAT & 156 & $150-244$ & 13 & & 0.850 & 0.921 \\
\hline SjP4 8 & $\begin{array}{l}\text { F : TTGTTGGGTAGTGATGGTAGG R: } \\
\text { TAGTTCATTCCACCTCTTGGA }\end{array}$ & TAA & 246 & $251-273$ & 6 & & 0.650 & 0.795 \\
\hline SjP54 & $\begin{array}{l}\text { F : TTAGGCTTGTTGGTGCTGATA R: } \\
\text { AGGTAAAGCAAATCCCATAGC }\end{array}$ & GGTA & 437 & $373-446$ & 9 & & 1.00 & 0.712 \\
\hline SjP58 & $\begin{array}{l}\text { F : TCCCAGTACCAATGTAGATGTG R: } \\
\text { CTAATAAAGTCGTCAAGGAGCA }\end{array}$ & $\mathrm{AAT}$ & 227 & $439-499$ & 12 & $* *$ & 0.800 & 0.921 \\
\hline sjP60 & $\begin{array}{l}\mathrm{F}: \text { CGATTCATTCATAGCCTGACT R: } \\
\text { GAATCCCATCACAGATTAACG }\end{array}$ & TAT & 155 & $134-165$ & 10 & & 0.900 & 0.867 \\
\hline SjP61 & $\begin{array}{l}\text { F : TCATCTTGTCACCAACTAGGC R: } \\
\text { GCTTGGAGGAGGCTAAAATAC }\end{array}$ & TAT & 188 & $158-238$ & 9 & & 0.700 & 0.679 \\
\hline SjP63 & 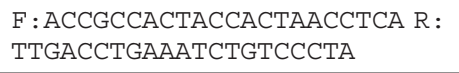 & TAA & 390 & $333-389$ & 13 & $* *$ & 0.800 & 0.904 \\
\hline SjP88 & $\begin{array}{l}\mathrm{F}: \text { GCTTTCCAGGCATAAACTTCAC R: } \\
\text { TCTCCTAATGATGGGAACAG }\end{array}$ & TAA & 408 & $380-417$ & 9 & & 0.950 & 0.887 \\
\hline
\end{tabular}

Sequences of microsatellites reported here have been deposited in GenBank [AB604199 - AB604218].

Note that the first two loci are from [10] and are included for comparative purposes.

The annealing temperature of PCRs for all loci is $55^{\circ} \mathrm{C}$.

${ }^{*} P<0.05{ }^{* *} P<0.01$ as determined in GenAIEx .

The search was undertaken using the software SciRoKo [11]. Following the above criteria, we identified 72 new loci for which primers were designed and synthesized. For 30 loci showing a single band of the correct size in a preliminary screening using an agarose gel, new forward primers were synthesized to permit M13 tailing $[12,13]$. All 30 loci were then used for genotyping of ten adult worms. Loci failing to provide clear signals in the expected size range, or that lacked polymorphism, were not considered further. Finally 20 new loci, plus 
two from [10], were optimized for PCR and used in the genotyping of 20 individual adult worms. Primer annealing temperatures were designed to be very similar with eventual multiplexing in mind.

The Sichuan Center for Disease Control and Prevention (SCDC) maintains $S$. japonicum lifecycles, including S. japonicum from infected snails sourced from Hubei and Anhui Provinces passed through rabbit hosts. For this study, existing samples were obtained from SCDC of adult schistosomes that were derived from a single passage of mixed Hubei and Anhui cercariae through a definitive host. Genomic DNA was extracted from 10 individual male and 10 female worms by incubation in hot sodium hydroxide with $\mathrm{pH}$ adjustment using a Tris solution (HotSHOT) [14]. The lysates were used as templates for PCR directly. Each worm was genotyped individually.

All PCRs were carried out in a $10 \mu \mathrm{l}$ reaction mixture containing $0.5 \mu \mathrm{l}$ of template DNA (about $17.5 \mathrm{ng}$ ), $0.5 \mu \mathrm{M}$ of each primer but $0.125 \mu \mathrm{M}$ of any forward primer with an M13 tail, and $5 \mu \mathrm{l}$ of $2 \mathrm{X}$ GoTaq Green Master Mix (Promega Corporation, WI, USA). For PCR amplification, templates were denatured at $94^{\circ} \mathrm{C}$ for 5 minutes followed by 30 cycles $\left(94^{\circ} \mathrm{C} 30\right.$ seconds, $55^{\circ} \mathrm{C}$ 45 seconds, $72^{\circ} \mathrm{C} 45$ seconds), and then by 8 cycles ( $94^{\circ} \mathrm{C} 30$ seconds, $53^{\circ} \mathrm{C} 45$ seconds, $72^{\circ} \mathrm{C} 45$ seconds), and a final extension at $72^{\circ} \mathrm{C}$ for 10 minutes. PCR products were separated using an $\mathrm{ABI} 3130 \mathrm{XL}$ automated DNA sequencer with ABI GS500 LIZ internal size standards. Results were read in GeneMapper 4.0 software (Applied Biosystems).

Estimates of heterozygosity were made, tests conducted for Hardy-Weinberg equilibrium and linkage disequilibrium, and alleles counted. The software package GenAlEx [15] was used for most data analysis. MicroChecker [16] was used to identify loci at which null (non-amplifying) alleles might be present. Use of the Bonferroni-adjusted 95\% confidence interval indicates that null alleles may occur only at locus $\mathrm{SjP9}$, one of the loci reported by [10].

Table 1 presents the findings for each locus, including numbers of alleles and observed heterozygosity $(H)$. Observed heterozygosity $(H o)$ at all loci was high, never below 0.6. A few loci deviated significantly from Hardy Weinberg expectations (Table 1), including SjP9 at which null alleles were suspected. Surprisingly, many pairs of loci were in linkage disequilibrium (data not shown). We consider this to be a consequence of the fact that adult worms were derived from pooled cercariae from infected snails: each snail is likely to yield many sibling/clonal cercariae, resulting in significant linkage disequilibrium (e.g. [10]). The pooling of cercariae from two distinct populations is likely to increase this effect. Previous workers [7] noted a high frequency of linkage disequilibrium in S. japonicum and considered it due to inbreeding and non-random mating.

The loci presented here are likely to be specific for S. japonicum. Blast searches of the draft genome of S. mansoni (http://www.sanger.ac.uk/Projects/S_mansoni/) failed to find any matches that would indicate conservation of flanking regions in both species (not shown). Searches of the draft genome of S. japonicum yielded only a single "hit" for each locus.

The microsatellite loci reported here are, with one exception (SjP54), perfect trinucleotide repeats, making scoring easier than for dinucleotide and/or compound repeats. The diversity of alleles and genotypes present in the populations we sampled demonstrate the utility of these markers for future studies on epidemiology of S. japonicum in eastern Asia. Finally, the obvious genetic diversity within field populations of S. japonicum in China demonstrated by these polymorphic microsatellite loci confirms the recent report of marked genetic diversity in this parasite detected by analysis of the $S$. japonicum transcriptome and proteome [4].

\section{Acknowledgements}

The authors wish to thank Kang Junxing, Director of the Sichuan Center for Disease Control and Prevention (Chengdu, People's Republic of China) for his continued support and collaboration. The authors also wish to acknowledge Zhong Bo, Ye Hong, Cui Lina, Chen Lin, Zhang Yi, Meng Xianhong of the Sichuan Center for Disease Control and Prevention for their contribution to the laboratory work. This work was supported in part by the $\mathrm{NIH/NSF}$ Ecology of Infectious Disease Program (grant no. 0622743) and the Emory Global Health Institute. The funders had no role in study design, data collection and analysis, decision to publish, or preparation of the manuscript.

\section{Author details}

'Institute of Parasitic Diseases, Sichuan Center for Disease Control and Prevention, Chengdu, Sichuan 610041, PR China. ${ }^{2}$ Department of Environmental Health, Rollins School of Public Health, Emory University, 1518 Clifton Rd. NE, Atlanta, Georgia 30322, USA. ${ }^{3}$ Department of Microbiology, Immunology \& Tropical Medicine, George Washington University Medical Center, 2300 Eye Street, NW, Washington, DC 20037, USA. ${ }^{4}$ Department of Environmental Health Sciences, School of Public Health, 50 University Hall, University of California, Berkeley, CA 94720, USA. ${ }^{5}$ School of Marine and Tropical Biology, James Cook University, Townsville, Queensland, 4811, Australia

\section{Authors' contributions}

$\mathrm{NX}, J \mathrm{R}, \mathrm{PB}$ and $\mathrm{DB}$ conceived of and designed the study, and were assisted by DQ and RS who coordinated the study. NX and YL carried out the molecular genetic studies, and were assisted by JR, PB and DB in analysing the results. NX, JR, PB and DB drafted the manuscript. All authors read and approved the final manuscript.

\section{Competing interests}

The authors declare that they have no competing interests.

Received: 8 December 2010 Accepted: 7 February 2011

Published: 7 February 2011

\section{References}

1. McManus DP, Gray DJ, Li YS, Feng Z, Williams GM, Stewart D, Rey-Ladino J, Ross AG: Schistosomiasis in the People's Republic of China: the era of the Three Gorges Dam. Clin Microbiol Rev 2010, 23:442-466. 
2. Zhou XN, Guo JG, Wu XH, Jiang QW, Zheng J, Dang H, Wang XH, Xu J, Zhu HQ, Wu GL, Li YS, Xu XJ, Chen HG, Wang TP, Zhu NQ, Xia G, Wang LY, Zhang SQ, Lin DD, Chen MG, Hao Y: Epidemiology of schistosomiasis in the People's Republic of China, 2004. Emerg Infect Dis 2007, 13:1470-1476.

3. Liang S, Yang CH, Zhong B, Qiu DC: Re-emerging schistosomiasis in hilly and mountainous areas of Sichuan, China. Bull World Health Organ 2006, 84:139-144.

4. Liu F, Lu J, Hu W, Wang SY, Cui SJ, Chi M, Yan Q, Wang XR, Song HD, Xu XN, Wang JJ, Zhang XL, Zhang X, Wang ZQ, Xue CL, Brindley PJ, McManus DP, Feng Z, Chen Z, Han ZG: Comparative transcriptomic and proteomic analyses of the human blood fluke, Schistosoma japonicum. PLoS Pathogens 2006, 2:e29

5. Xu J, Rong R, Zhang $H Q$, Shi $C J$, Zhu XQ, Xia CM: Sensitive and rapid detection of Schistosoma japonicum DNA by loop-mediated isothermal amplification (LAMP). Int J Parasitol 2010, 40:327-331.

6. Hung YW, Remais J: Quantitative Detection of Schistosoma japonicum Cercariae in Water by Real-Time PCR. PLoS Negl Trop Dis 2008, 2:e337.

7. Shrivastava J, Qian BZ, McVean G, Webster JP: An insight into the genetic variation of Schistosoma japonicum in mainland China using DNA microsatellite markers. Mol Ecol 2005, 14:839-849.

8. Shrivastava J, Barker GC, Johansen MV, Zhou XN, Aligui GD, McGarvey ST, Webster JP: Isolation and characterization of polymorphic DNA microsatellite markers from Schistosoma japonicum. Mol Ecol Notes 2003, 3:406-408.

9. Schistosoma japonicum Genome Sequencing and Functional Analysis Consortium: The Schistosoma japonicum genome reveals features of host-parasite interplay. Nature 2009, 460:345-351.

10. Yin M, Hu W, Mo X, Wang SY, Brindley PJ, McManus DP, Davis GM, Feng Z, Blair D: Multiple near-identical genotypes of Schistosoma japonicum can occur in snails and have implications for population-genetic analyses. Int J Parasitol 2008, 38:1681-1691.

11. Kofler R, Schlotterer C, Lelley T: SciRoKo: a new tool for whole genome microsatellite search and investigation. Bioinformatics 2007, 23:1683-1685.

12. Schuelke M: An economic method for the fluorescent labeling of PCR fragments. Nature Biotech 2000, 18:233-234.

13. Bandelj D, Jakse J, Javornik B: Amplification of fluorescent-labelled microsatellite markers in olives by a novel, economic method. Acta Agric Slovenica 2004, 83:323-329.

14. Truett E, Mynatt LR, Truett AA, Walker AJ, Warman LM: Preparation of PCRquality mouse genomic DNA with hot sodium hydroxide and Tris (HotSHOT). BioTechniques 2000, 29:52-54.

15. Peakall R, Smouse PE: GENALEX 6: genetic analysis in Excel. Population genetic software for teaching and research. Mol Ecol Notes 2006, 6:288-295.

16. Van Oosterhout C, Hutchinson WF, Wills DPM, Shipley P: MICRO-CHECKER: software for identifying and correcting genotyping errors in microsatellite data. Mol Ecol Notes 2004, 4:535-538.

doi:10.1186/1756-3305-4-13

Cite this article as: Xiao et al.: Polymorphic microsatellites in the human bloodfluke, Schistosoma japonicum, identified using a genomic resource. Parasites \& Vectors 2011 4:13.

\section{Submit your next manuscript to BioMed Central and take full advantage of:}

- Convenient online submission

- Thorough peer review

- No space constraints or color figure charges

- Immediate publication on acceptance

- Inclusion in PubMed, CAS, Scopus and Google Scholar

- Research which is freely available for redistribution

Submit your manuscript at www.biomedcentral.com/submit
Biomed Central 